\title{
Cloning of chromosomal $\beta$-lactamase genes from Yersinia enterocolitica
}

\author{
Asunción SEOANe and JuAn M. García Lobo* \\ Departamento de Biología Molecular, Universidad de Cantabria, Poligono de Cazoña s/n, 39011 Santander, Spain
}

(Received 24 April 1990; revised 19 July 1990; accepted 28 September 1990)

\begin{abstract}
Two $\beta$-lactamase genes present in the chromosome of Yersinia enterocolitica have been cloned individually into the plasmid pACY184 and expressed in Escherichia coli. The gene for broad-spectrum $\beta$-lactamase I ('A') was cloned from a strain belonging to the $O: 3$ serotype, and the gene for (cephalosporinase) $\beta$-lactomase II ('B') was cloned from a strain of the $0: 5 \mathrm{~b}$ serotype. The properties of the $\beta$-lactamases expressed in $E$. coli are similar to those previously described in $Y$. enterocolitica.
\end{abstract}

\section{Introduction}

Chromosomal $\beta$-lactamase genes are common in Gramnegative bacteria. The enzymes encoded by these genes are usually specific for the hydrolysis of cephalosporins, are inducible and have an alkaline pI. High levels of enzymes of this type are associated with resistance to the newer cephalosporins. Chromosomal $\beta$-lactamase genes from Escherichia coli, Citrobacter freundii, Shigella sonnei (Bergström et al., 1983), Enterobacter claocae (Nicolas et al., 1987) and Klebsiella pneumoniae (Arakawa et al., 1986) have been cloned and are well characterized. Genes from Serratia marcescens (Joris et al., 1986) and Proteus vulgaris (Maejima et al., 1987) have been less well studied. The genes from E. coli, C. freundii, S. sonnei and Ent. cloacae are related and the $\beta$-lactamases they produce are considered as a homogeneous group and referred to as class C $\beta$-lactamases (Jaurin \& Grundström, 1981).

Yersinia enterocolitica is also classified among the enterobacteria and is resistant to benzylpenicillin and cephalothin, and sometimes to ampicillin and carbenicillin, due to the production of chromosomal $\beta$-lactamases. Previous studies showed that strains of the $O: 3$ serotype produce two different $\beta$-lactamases. One, referred to as the 'A' enzyme, is a broad-spectrum enzyme hydrolysing carbenicillin. Its molecular mass has been estimated to be $20 \mathrm{kDa}$ and its $\mathrm{pI}$ to be $8 \cdot 7$. It is produced constitutively. The other, called the ' $\mathrm{B}$ ' enzyme, is an inducible cephalosporinase of $34 \mathrm{kDa}$ which focuses as two bands of pI 5.3 and 5.7. It has been reported also that

Abbreviations: 6-APA, 6-aminopenicillanic acid; PADAC, pyridinium-2-azo-p-dimethylaniline cephalosporin.
$Y$. enterocolitica strains of $\mathrm{O}: 5 \mathrm{~b}$ serotype only express the 'B' enzyme (Cornelis, 1981).

In this paper we report the cloning of the chromosomal genes coding for two $\beta$-lactamases in $Y$. enterocolitica, together with a preliminary analysis of the kinetic properties of the enzymes. The $\beta$-lactamases are referred to here as types I and II, rather than A and B, to avoid confusion with the sequence classes of $\beta$-lactamases.

\section{Methods}

Bacterial strains and plasmids. Y. enterocolitica strain Y56 (O:3) was isolated from the environment by L. Rodríguez Solórzano (Santander, Spain). Its serotype was kindly determined by H. H. Mollaret (Institute Pasteur, Paris, France). Y. enterocolitica IP97 (also from L. Rodríguez Solórzano) belongs to the $\mathrm{O} 5: \mathrm{b}$ serotype. As recipient for the cloning experiments we used $E$. coli $\mathrm{HB} 101\left(\mathrm{~F}^{-} h s d R\right.$ hsdM recAl3 proA2 leuB6 thi-1 ara-14 lacYl galK2 xyl-5 mtl-1 supE44 rpsL20).

$\beta$-Lactamase activities and kinetic parameters were detemined on enzymes isolated from $E$. coli $\mathrm{K} 12$ strain MI1443 [ $\Delta(f r d$-ampC) $r p s L]$ containing the appropriate plasmids. The cloning vector used was the plasmid pACYC184 (Cmr Tetr Rep p15A) (Chang \& Cohen, 1978).

Media and antibiotics. L-broth and L-agar (Maniatis et al., 1982) were routinely used for bacterial growth. Ampicillin was added to the agar at $50 \mu \mathrm{g} \mathrm{ml}^{-1}$ and chloramphenicol at $25 \mu \mathrm{g} \mathrm{ml}^{-1}$.

DNA preparation and analysis. Chromosomal DNA was prepared as described by Silhavy et al. (1984). Plasmid DNA was purified by alkaline lysis followed by phenol extraction and ethanol precipitation. Agarose for gel electrophoresis was prepared in Tris/borate buffer, and gels were made essentially as described by Maniatis et al. (1982). Restriction enzymes were obtained from Boehringer Mannheim and used under the conditions recommended by the supplier. Restriction fragments were usually separated in horizontal $1 \%$ agarose gels. HindIII and EcoRI-HindIII fragments of $\lambda$ DNA were used as molecular size standards. 
Cloning procedure. Chromosomal DNA from $Y$. enterocolitica was partially digested with the restriction endonuclease Sau3AI. This DNA was ligated into the BamHI site of the plasmid vector pACYC184 with T4 DNA ligase (New England Biolabs). Ligated DNA was introduced into competent cells of $E$. coli $\mathrm{HB} 101$ and recombinants were selected on agar containing ampicillin.

MIC determination. Minimal inhibitory concentrations were determined on Mueller-Hinton agar (Difco) containing twofold serial dilutions of the antibiotics. The inoculum size was $10^{4}$ cells.

$\beta$-Lactamase assays. $\beta$-Lactamase activity in crude extracts was determined spectrophotometrically (Ross \& O'Callaghan, 1975) at room temperature with $100 \mu \mathrm{M}$-cephaloridine as substrate. To prepare cell-free extracts, $50 \mathrm{ml}$ cultures were grown in $\mathrm{LB}$ to an $\mathrm{OD}_{420}$ of 0.8 either in the presence (induced) or the absence (uninduced) of $125 \mu \mathrm{g}$ 6-aminopenicillanic acid (6-APA) $\mathrm{ml}^{-1}$. Cells were resuspended in $1 \mathrm{ml}$ $0.1 \mathrm{M}$-phosphate buffer $\mathrm{pH} 7.0$ and disrupted by ultrasonic treatment for $1 \mathrm{~min}$ (three $20 \mathrm{scycles}$ with 30 s pauses) at $4^{\circ} \mathrm{C}$. Crude extracts were cleared of cell debris by centrifugation at $12000 \mathrm{~g}$ for $1 \mathrm{~h}$ at $4^{\circ} \mathrm{C} . K_{\mathrm{m}}$ and $V$ values were calculated by a least-squares fit of a double reciprocal plot of initial velocities at eight different substrate concentrations. The following wavelengths were used for the enzyme assays: ampicillin, benzylpenicillin and carbenicillin, $235 \mathrm{~nm}$; cefamandole, $272 \mathrm{~nm}$; cefotaxime, $225 \mathrm{~nm}$; cefoxitin, $260 \mathrm{~nm}$; cephaloridine, $255 \mathrm{~nm}$; cephalothin, $262 \mathrm{~nm}$. Relative $V$ and relative $V / K_{\mathrm{m}}$ values were used to compare enzyme activities, as recommended by Bush \& Sykes (1986). Protein concentrations in the extracts were determined by the method of Bradford (1976). Osmotic fluids, prepared as described by Nossal \& Heppel (1966), were used to determine $\beta$ lactamase molecular mass by SDS-polyacrylamide gel electrophoresis (Laemmli, 1970). Native electrophoresis on cellulose acetate using $50 \mathrm{~mm}$-phosphate buffer $(\mathrm{pH} 7 \cdot 0)$ followed by activity staining with pyridinium-2-azo-p-dimethylaniline cephalosporin (PADAC, Calbiochem) was also used to visualize $\beta$-lactamases (Jones et al., 1982).

DNA hybridization. DNA restriction fragments to be used as probes were purified by electroelution from agarose gels. They were labelled with digoxigenin-modified dUTP using the Klenow fragment of $E$. coli DNA polymerase $I$ in a random primed reaction (Boehringer Mannheim). DNA to be probed was fragmented and transferred to nitrocellulose as described by Southern (1975). Hybridization was carried out in plastic bags at $42^{\circ} \mathrm{C}$ in the presence of $50 \%(\mathrm{v} / \mathrm{v})$ formamide.

Membranes were washed twice for 5 min with $2 \times$ SSC containing $0.1 \%$ SDS at room temperature and twice for $15 \mathrm{~min}$ in $0.1 \times \mathrm{SSC}, 0.1 \%$ SDS at $68^{\circ} \mathrm{C}(1 \times \mathrm{SSC}$ is $0.15 \mathrm{M}-\mathrm{NaCl}, 0.015 \mathrm{~m}$-trisodium citrate, $\mathrm{pH}$ 7.0). Hybridized filters were incubated with an anti-digoxigenin-DNA antibody tagged with alkaline phosphatase and then with the colour substrate 5-bromo-4-chloro-3-indolyl phosphate and nitrobluetetrazolium (Boehringer Mannheim Nonradioactive Labelling and Detection Kit).

\section{Results}

\section{Cloning of the blaA gene, encoding $\beta$-lactamase type I}

Chromosomal DNA from $Y$. enterocolitica strain Y56 (serotype O:3) was cloned in pACYC184. Colonies containing recombinant plasmids were selected initially on the basis of their $\mathrm{Ap}^{\mathrm{r}} \mathrm{Cm}^{\mathrm{r}} \mathrm{Tc}^{\mathrm{s}}$ phenotype. One of these colonies, containing plasmid pSU601, encoded a $\beta$ -

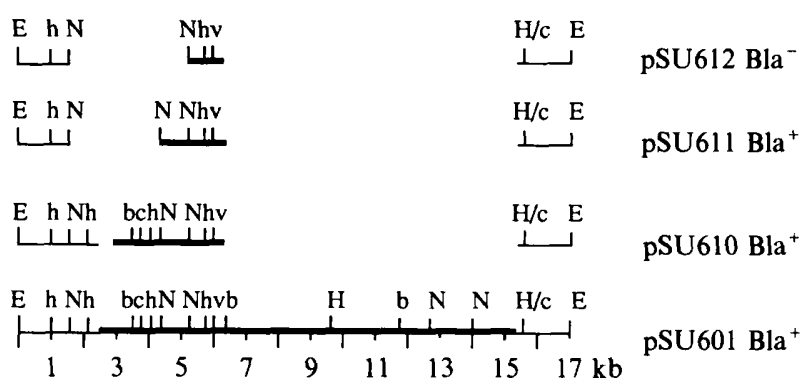

Fig. 1. Restriction map of the recombinant plasmids expressing $\beta$-lactamase type I and some of their derivatives. Thin lines represent the vector pACYC184 and thick lines the $Y$. enterocolitica Y56 chromosomal DNA insert. Restriction enzymes: E, EcoRI; h, HindII; N, NruI; b, BstEII; c, ClaI; v, EcoRV; H, HindIII.

pSU623 $\mathrm{Bla}^{-}$

Fig. 2. Restriction maps of plasmid pSU602, expressing $\beta$-lactamase type II, and of its derivatives pSU622 and pSU623. Thin lines represent the vector pACYC184 and thick lines the $Y$. enterocolitica IP97 chromosomal DNA insert. Key to restriction enzymes as for Fig. 1, plus B, BamHI.

lactamase. This plasmid has a $13 \mathrm{~kb}$ insert in the BamHI site of pACYC184. The MICs of several $\beta$-lactam antibiotics for $E$. coli $\mathrm{HB} 101$ carrying this plasmid are shown in Table 1. Since this strain showed resistance towards cephalosporins and carbenicillin, it was assumed to contain the gene coding for the type I enzyme. A restriction map pSU601 is shown in Fig. 1. To localize the $\beta$-lactamase gene, pSU601 was partially digested with Sau3AI and subcloned into BamHI-linearized pACYC184. This resulted in the isolation of plasmid pSU610, with a $3.3 \mathrm{~kb}$ insert and capable of producing a $\beta$-lactamase that was indistinguishable from that produced by pSU601.

Plasmid pSU610 DNA produced three NruI fragments, of $4.4,2.3$ and $0.8 \mathrm{~kb}$ (Fig. 1). When these fragments were ligated and introduced into $E$. coli $\mathrm{HB} 101$, selecting for ampicillin resistance, plasmid pSU611, was isolated which contained only the 4.4 and $0.8 \mathrm{~kb}$ fragments. This indicated that the $2.3 \mathrm{~kb} \mathrm{NruI}$ fragment was not essential for $\beta$-lactamase production. A second type of recombinant was isolated on chloramphenicol agar and was susceptible to ampicillin. The plasmid from one such isolate, pSU612, was analysed and shown to lack just the $0.8 \mathrm{~kb} \mathrm{NruI}$ fragment. Taken together, the subclones indicate that the gene coding for $\beta$-lactamase type $I$ is located on the $1.9 \mathrm{~kb}$ DNA 
Table 1. MICs of representative $\beta$-lactam antibiotics for various strains

Abbreviations for antibiotics and limits between which MICs were determined: AP, ampicillin (1-1024 $\left.\mu \mathrm{g} \mathrm{ml}^{-1}\right)$; CB, carbenicillin (1-1024 $\left.\mu \mathrm{g} \mathrm{ml}^{-1}\right)$; CTN, cephalothin (1-1024 $\left.\mu \mathrm{g} \mathrm{ml}^{-1}\right)$; CFM, cefamandole (1-128 $\left.\mu \mathrm{g} \mathrm{ml}^{-1}\right)$; CFR, cephaloridine (1-256 $\left.\mathrm{g} \mathrm{ml}^{-1}\right)$; CXT, cefoxitin (1-256 $\left.\mu \mathrm{g} \mathrm{m}^{-1}\right)$; CTX, cefotaxime $\left(0.03-32 \mu \mathrm{g} \mathrm{ml}^{-1}\right)$. The values reported are representative of three independent experiments.

\begin{tabular}{lrrrrrrr}
\hline \hline \multicolumn{1}{c}{ Strain } & \multicolumn{7}{c}{ MIC $\left(\mu \mathrm{g} \mathrm{m \textrm {m } ^ { - 1 } )}\right.$} \\
\cline { 2 - 8 } & AP & CB & CTN & CFR & CFM & CXT & CTX \\
\hline E. coli HB101 & 2 & 4 & 2 & 2 & $<1$ & 2 & $<0 \cdot 03$ \\
Y. enterocolitica Y56 & 16 & 256 & 128 & 8 & 4 & 2 & $0 \cdot 06$ \\
E. coli HB101(pSU601) & 256 & $>1024$ & 128 & 16 & 32 & 2 & $0 \cdot 12$ \\
E. coli HB101(pSU610) & 1024 & $>1024$ & 128 & 16 & 32 & 2 & $0 \cdot 12$ \\
E. coli HB101(pSU611) & 1024 & $>1024$ & 128 & 16 & 32 & 2 & $0 \cdot 25$ \\
E. coli HB101(pSU612) & 2 & 4 & 2 & 2 & $<1$ & 2 & $<0 \cdot 03$ \\
Y. enterocolitica IP97 & 16 & 1 & 1024 & 64 & 4 & 16 & $0 \cdot 12$ \\
E. coli HB101(pSU602) & 256 & 8 & 512 & 128 & 8 & 64 & $0 \cdot 50$ \\
E. coli HB101(pSU622) & 512 & 16 & 1024 & 128 & 16 & 64 & $4 \cdot 0$ \\
E. coli HB101(pSU623) & 2 & 4 & 2 & 2 & $<1$ & 2 & $<0 \cdot 03$ \\
\hline \hline
\end{tabular}

Table 2. $\beta$-Lactamase activity expressed from Y. enterocolitica Y56 and IP97 and from the cloned bla genes of Y. enterocolitica in E. coli K12 strain MI1443

Bacterial cells were grown to the end of the exponential phase, in either the presence (induced) or the absence (uninduced) of 6-APA $\left(125 \mu \mathrm{g} \mathrm{ml}^{-1}\right)$, and crude extracts were prepared. The substrate was $100 \mu \mathrm{M}$-cephaloridine. The values given are representative of three independent experiments.

\begin{tabular}{lcccc}
\hline \hline & \multicolumn{4}{c}{$\beta$-Lactamase activity [units (mg protein) ${ }^{-1}$ ] } \\
\cline { 2 - 5 } \multicolumn{1}{c}{ Strain } & Enzyme & $\begin{array}{c}\text { Uninduced } \\
(a)\end{array}$ & $\begin{array}{c}\text { Induced } \\
(b)\end{array}$ & $\begin{array}{c}\text { Ratio } \\
b / a\end{array}$ \\
\hline Y. enterocolitica & & & & \\
Y56 & I + II & 0.036 & 0.038 & 1 \\
IP97 & II & 0.017 & 0.152 & 8.9 \\
E.coli & & & & \\
MI1443 & - & $<0.001$ & $<0.001$ & 1 \\
MI1443(pSU611) & I & 0.071 & 0.078 & 1 \\
MI1443(pSU602) & II & 0.054 & 0.162 & 3 \\
MI1443(pSU622) & II & 1.44 & 1.55 & 1 \\
\hline \hline
\end{tabular}

fragment between the $N r u I$ site at coordinate 4.4 and the BstEII site at 6.3, of pSU601 (Fig. 1).

\section{Cloning of the blaB gene, encoding $\beta$-lactamase type II}

Chromosomal DNA from $Y$. enterocolitica strain IP97 (serotype $\mathrm{O}: 56$ ) was fragmented and cloned into pACYC184. Recombinants expressing $\beta$-lactamase were selected on ampicillin agar. Plasmid pSU602, containing a $2.7 \mathrm{~kb}$ insert, was isolated from one of these recombinants. A restriction map of this plasmid is shown in Fig. 2. Deletion of the EcoRI fragment from 0 to $3.5 \mathrm{~kb}$ resulted in plasmid pSU622, which still contained an active $\beta$ lactamase gene. Deletion of the $1.2 \mathrm{~kb}$ Hind III fragment from pSU602 gave plasmid pSU623, which no longer conferred resistance to $\beta$-lactams. The MICs of different $\beta$-lactam antibiotics for $E$. coli $\mathrm{HB101}$ (pSU602), in particular its sensitivity to carbenicillin (Table 2), indicated that the $\beta$-lactamase encoded by this plasmid was the type II enzyme, the only type expressed by the strains of $Y$. enterocolitica belonging to the $\mathrm{O}: 5 \mathrm{~b}$ serotype.

\section{Visualization of $\beta$-lactamases}

The identity of the $\beta$-lactamase encoded by the recombinant plasmids was determined by electrophoresis of crude bacterial extracts on cellulose acetate and visualization of $\beta$-lactamases by staining with PADAC. This technique showed that $E$. coli MI1443 (pSU622) and $Y$. 


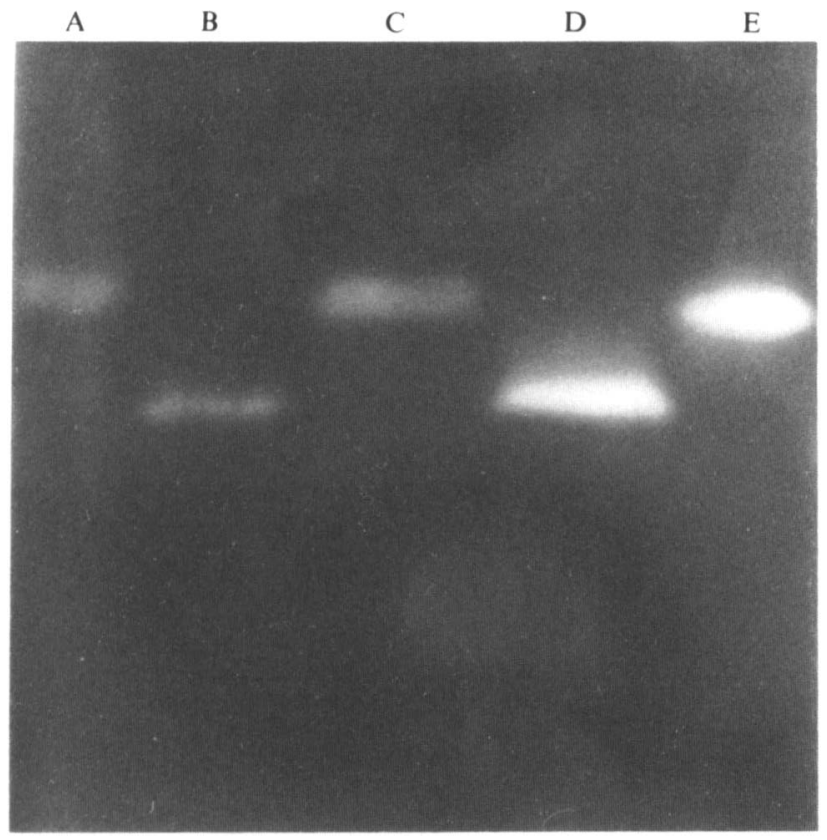

Fig. 3. Cellulose acetate electrophoresis of crude extracts containing $\beta$-lactamases after staining with the chromogenic substrate PADAC $(50 \mu \mathrm{M})$. Ent . cloacae ampC $\beta$-lactamase cloned in plasmid pEC1C was included as a control. The direction of electrophoresis was from top (negative) to bottom (positive). The extracts were obtained from the following strains: A, Y. enterocolitica Y56; B, Y. enterocolitica IP97; C, E. coli MI1443(pSU611); D, E. coli MI1443(pSU622); E, E. coli MI1443(pEC1C) (Nicolas et al., 1987). enterocolitica IP97 expressed $\beta$-lactamases with the same mobility. Similarly, E. coli MI1443(pSU611) and $Y$. enterocolitica Y56 showed single bands of identical mobility under these conditions. The presumptive type I and II $\beta$-lactamases were easily differentiated from each other by using this native gel system (Fig. 3).

\section{Properties of $\beta$-lactamases I and II}

$\beta$-Lactamase I, expressed by $E$. coli MI1443(pSU611), showed an apparent molecular mass of $26 \mathrm{kDa}$ in SDSpolyacrylamide gels. The specific activity of the enzyme was measured in crude bacterial extracts and the results in Table 2 indicate that the gene encoding this enzyme is not inducible either in $Y$. enterocolitica or in $E$. coli containing recombinant plasmids. $\beta$-Lactamase II showed an apparent size of $39 \mathrm{kDa}$ in SDS-polyacrylamide gels. The specific activity measurements of this enzyme (Table 2) indicate that it is encoded by a gene that is inducible by $125 \mu \mathrm{M}-6-\mathrm{APA}$ in $Y$. enterocolitica IP97 but not in $Y$. enterocolitica Y56. E. coli MI1443(pSU602) showed an intermediate, threefold increase in $\beta$-lactamase production in the presence of 6APA. The plasmid of pSU622 produced a very high level of $\beta$-lactamase irrespective of the presence of 6-APA.

The kinetic parameters of $\beta$-lactamases I and II were measured (Table 3). $\beta$-Lactamase I from $E$. coli

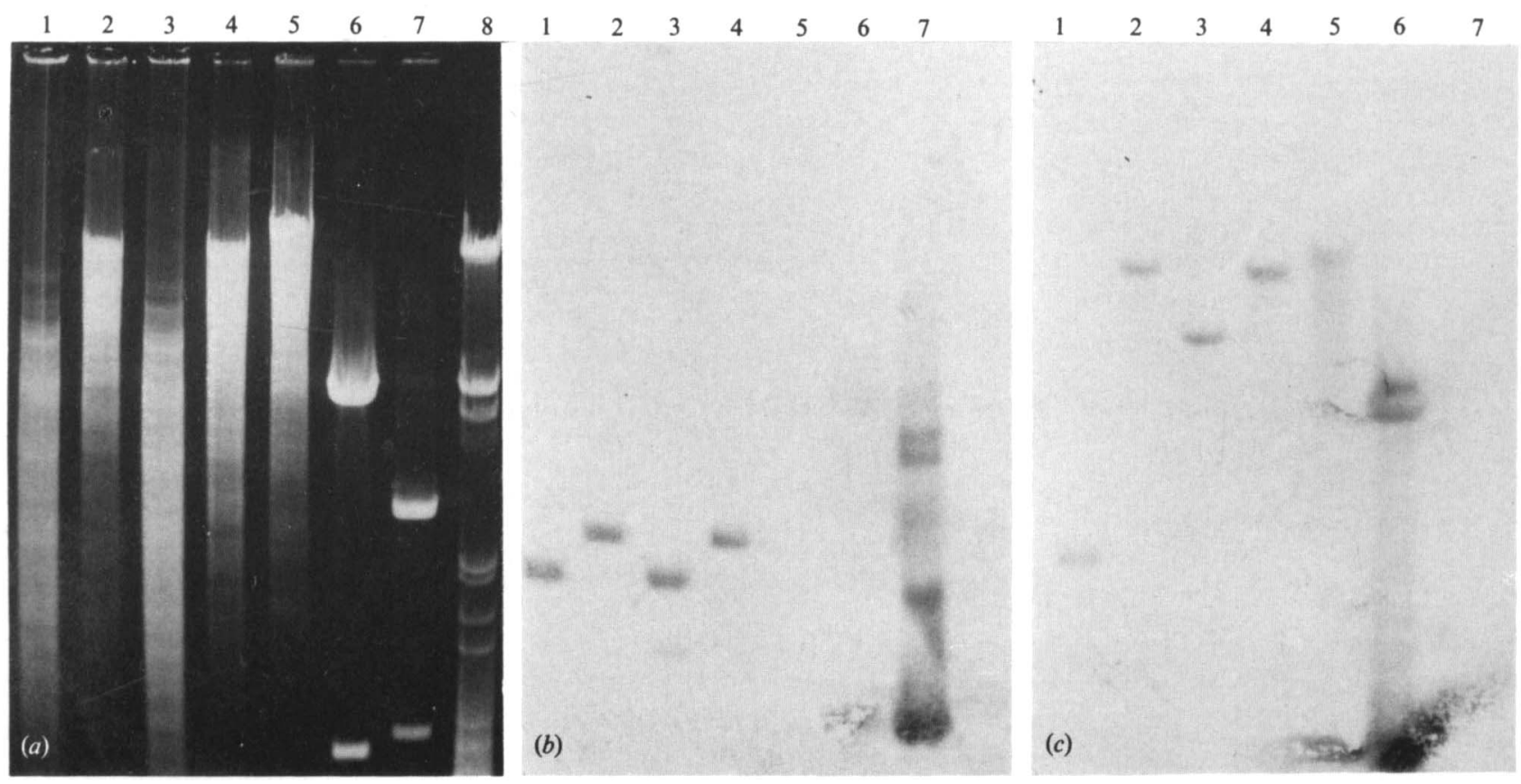

Fig. 4. Southern blot analysis of $Y$. enterocolitica chromosomal DNA. (a) The agarose gel. (b) Results with the blaB gene probe; (c) results with the blaA gene probe. The same samples were loaded in the same lane in the three panels ( $\lambda$ DNA is only marked in panel $a$ ). DNA in lane 1, Y. enterocolitica Y56 HindII digested; lane 2, Y. enterocolitica Y56 HindIII digested; lane 3, Y. enterocolitica IP97 HindII digested; lane 4, Y. enterocolitica IP97 HindIII digested; lane 5, E. coli HB101 HindIII digested; lane 6, pSU611 NruI digested; lane 7, pSU622 HindIII/BamHI digested; lane 8, $\lambda$ DNA EcoRI/HindIII digested. 
Table 3 Kinetic parameters of hydrolysis of $\beta$-lactam antibiotics by Y. enterocolitica $\beta$-lactamases I and II from E. coli MI1443(pSU611) and E. coli MI1443(pSU622), respectively

$V$ is expressed in $\mu \mathrm{mol}$ hydrolysed (mg protein) ${ }^{-1} \mathrm{~min}^{-1}$. The relative $V$ and relative $V / K_{\mathrm{m}}$ for each antibiotic were normalized with respect to cephaloridine. The results reported are representative of three independent experiments.

\begin{tabular}{|c|c|c|c|c|c|c|c|c|}
\hline \multirow[b]{2}{*}{ Antibiotic } & \multicolumn{4}{|c|}{$\beta$-Lactamase I } & \multicolumn{4}{|c|}{$\beta$-Lactamase II } \\
\hline & $V$ & $\underset{V}{\text { Relative }}$ & $\begin{array}{c}K_{\mathrm{m}} \\
(\mu \mathrm{M})\end{array}$ & $\begin{array}{l}\text { Relative } \\
V / K_{\mathrm{m}}\end{array}$ & $V$ & $\underset{V}{\text { Relative }}$ & $\begin{array}{c}K_{\mathrm{m}} \\
(\mu \mathrm{M})\end{array}$ & $\begin{array}{c}\text { Relative } \\
V / K_{\mathrm{m}}\end{array}$ \\
\hline Cephaloridine & 0.65 & 100 & $793 \cdot 6$ & 100 & $2 \cdot 29$ & 100 & 90.9 & 100 \\
\hline Cephalothin & 1.62 & 249 & 833.3 & $237 \cdot 3$ & $14 \cdot 3$ & $624 \cdot 4$ & $337 \cdot 8$ & 178.4 \\
\hline Cefamandole & 0.52 & 80 & $333 \cdot 3$ & $190 \cdot 6$ & ND & & & \\
\hline Cefoxitin & ND & & & & 0.46 & $20 \cdot 3$ & $81 \cdot 9$ & $22 \cdot 5$ \\
\hline Cefotaxime & ND & & & & ND & & & \\
\hline Ampicillin & 0.21 & $32 \cdot 1$ & $357 \cdot 1$ & $71 \cdot 1$ & $0 \cdot 115$ & $5 \cdot 02$ & 533.9 & $0 \cdot 85$ \\
\hline Carbenicillin & 0.08 & $12 \cdot 3$ & 500 & $19 \cdot 5$ & ND & & & \\
\hline Benzylpenicillin & 0.25 & $38 \cdot 5$ & 15.9 & $1926 \cdot 5$ & 1.21 & $52 \cdot 8$ & $7 \cdot 14$ & 677.8 \\
\hline
\end{tabular}

$\mathrm{ND}$, Not detected: hydrolysis rates were too low to be detected after $2 \mathrm{~h}$ of incubation.

MI1443(pSU611) efficiently hydrolysed ampicillin and benzylpenicillin as well as cephalothin, cephaloridine and cefamandole. Carbenicillin was also hydrolysed, but less efficiently. $\beta$-Lactamase II, from $E$. coli MI1443(pSU622) hydrolysed mainly cephalosporins and benzylpenicillin.

Southern blot analysis of $Y$. enterocolitica chromosomal DNA

Chromosomal DNA from $Y$. enterocolitica strains Y56 and IP97, belonging to the $\mathrm{O}: 3$ and $\mathrm{O}: 5 \mathrm{~b}$ serotypes, respectively, was digested with HindIII or HindII, transferred to nitrocellulose and separately hybridized with probes presumed to contain the two cloned bla genes (Fig. 4). The probe for bla $A$ was a $0.8 \mathrm{~kb} \mathrm{NruI}$ fragment prepared from pSU611 (Fig. 1), and that for blaB was the $0.9 \mathrm{~kb}$ HindIII/BamHI fragment from pSU622 (Fig. 2). Both strains of $Y$. enterocolitica appeared identical when their chromosomes were hybridized with the blaB gene probe, with a $2.3 \mathrm{~kb}$ HindIII fragment and a $1.8 \mathrm{~kb}$ HindII fragment present in both cases. However, when the two strains were probed for the blaA gene, the same $H$ HindII fragment of about $10 \mathrm{~kb}$ was present in the two strains but they showed different HindII fragments. The O:3 serotype strain (Y56) showed a $1.8 \mathrm{~kb}$ HindII fragment (probably located between 4.1 and $5.9 \mathrm{~kb}$ in pSU601), whereas the size of the HindII fragment from the $\mathrm{O}: 5 \mathrm{~b}$ strain (IP97) was about $7 \mathrm{~kb}$ (Fig. 4).

\section{Discussion}

The presence of two $\beta$-lactamases among $Y$. enterocolitica has been already reported. Here we describe the cloning of the genes encoding two distinct $\beta$-lactamases from different strains of $Y$. enterocolitica and their expression in E. coli.

The characteristics of these enzymes, when expressed in E. coli, largely agree with those obtained previously. The gene encoding $\beta$-lactamase I was inducible in $Y$. enterocolitica IP97 and to a lesser extent also in E. coli MI1443(pSU602). This result is consistent with those obtained for other chromosomal-mediated cephalosporinases (Nicolas et al., 1987). However, the high level of $\beta$-lactamase II expression in $E$. coli strains containing pSU622 (see Table 2) suggests that this gene could be subject to negative regulation in the parental Yersinia strain. $Y$. enterocolitica $\mathrm{Y} 56$ is believed to contain active blaA and blaB genes (Cornelis, 1981). Southern hybridization experiments showed that there were sequences homologous to both blaA and blaB probes in the Y56 chromosome. However, there is circumstantial evidence from our results suggesting poor expression of the blaB gene from $Y$. enterocolitica Y56.

Similarly, it has been shown that strains belonging to the $\mathrm{O}: 5 \mathrm{~b}$ serotype only produced the type II $\beta$-lactamase (Cornelis, 1981). Again, the Southern hybridization showed that the chromosome of the $\mathrm{O}: 5 \mathrm{~b}$ strain IP97 hybridized with both blaA and blaB gene probes. However, the HindII fragments from Y56 and IP97 hybridizing with the blaA probe were different. This difference, which relates to a HindII site, could be involved in the already reported lack of blaA expression in strains of $\mathrm{O}: 5 \mathrm{~b}$ serotype.

In view of the above findings it is tempting to speculate that when two $\beta$-lactamase genes are simultaneously present in the chromosome of a particular bacterium, they evolve in such a way that only one is active (and the other perhaps finally lost). This could account, at least in part, for the distribution of 
$\beta$-lactamase genes in the chromosomes of present-day enterobacteria.

The data obtained on these enzymes support the view that $\beta$-lactamase II is a cephalosporinase, probably related to the chromosomal enzymes of other Gramnegative organisms (molecular class $\mathrm{C}$ ). The $\beta$-lactamase I could be similar to the chromosomal $\beta$-lactamase from Klebsiella pneumoniae, which confers resistance to carbenicillin and has been shown to be related to the plasmidic TEM-type enzyme (class A) (Arakawa et al., 1986). The differences between these two genes were reinforced by our preliminary hybridization studies, which showed that the two $\beta$-lactamase genes do not share extensive sequence homology. We are now determining the nucleotide sequences of these genes, which should clarify the molecular classification of these two enzymes.

The cloning of these two $\beta$-lactamase genes from the $Y$. enterocolitica chromosome should be helpful in understanding the relationship among $\beta$-lactamase genes in Gram-negative bacteria. In addition they will be used to investigate the contribution of each enzyme to the resistance of $Y$. enterocolitica to $\beta$-lactams and may also be useful for studying gene expression in Y. enterocolitica.

We thank Luciano Rodriguez for the gift of $Y$. enterocolitica strains Y56 and IP97. This work was supported in part by grant PB87-0802 from the Spanish Ministerio de Educacion y Ciencia and from the Comisión Mixta Universidad-Diputación de Cantabria.

\section{References}

Arakawa, Y., Ohta, M., Kido, N., Fuji, Y., Komatsu, T. \& Kato, N. (1986). Close evolutionary relationship between the chromosomally encoded $\beta$-lactamase gene of Klebsiella pneumoniae and the TEM $\beta$-lactamase gene mediated by R plasmids. FEBS Letters 207, 69-74.

Bergström, S., Lindberg, F. P., ÖlsSon, O. \& Normark, S. (1983). Comparison of the overlapping $\mathrm{frd}$ and $a \mathrm{mpC}$ operons of Escherichia coli with the corresponding DNA sequences of other gram-negative bacteria. Journal of Bacteriology 155, 1297-1305.
BRADFORD, M. M. (1976). A rapid and sensitive method for the quantitation of microgram quantities of protein utilizing the principle of protein dye binding. Analytical Biochemistry 72, 248-254.

BUSH, K. \& SYKES, R. B. (1986). Methodology for the study of $\beta$ lactamases. Antimicrobial Agents and Chemotherapy 30, 6-10.

Chang, A. C. Y. \& CoHEN, S. N. (1978). Construction and characterization of amplificable muticopy DNA cloning vehicles derived from the P15A cryptic miniplasmid. Journal of Bacteriology 134, 1141-1156.

CORNELIS, G. (1981). Antibiotic resistance in Yersinia enterocolitica. In Yersinia enterocolitica, pp. 55-71. Edited by E. J. Bottone. Boca Raton: CRC Press.

JAURIN, B. \& GRUNDSTRÖM, T. (1981). ampC cephalosporinase of Escherichia coli $\mathrm{K}-12$ has a different evolutionary origin from that of $\beta$-lactamases of the penicillinase type. Proceedings of the National Academy of Sciences of the United States of America 78, 4897-4901.

JoNES, R. N., WILSON, H. W. \& Novick, W. J. JR. (1982). In vitro evaluation of pyridine-2-azo-p-dimethylaniline cephalosporin, a new diagnostic chromogenic reagent, and comparison with nitrocefin, cephacetrile, and other $\beta$-lactam compounds. Journal of Clinical Microbiology 15, 677-683.

Joris, B., De Meester, F., Galleni, M., Masson, S., Dusart, J., Frere, K. M., Van BeEmun, J., Bush, K. \& Sykes, R. (1986). Properties of the class $C \beta$-lactamase from Serratia marcescens. Biochemical Journal 239, 581-586.

LaEMmLI, U. K. (1970). Cleavage of structural proteins during the assembly of the head of bacteriophage T4. Nature, London 227, 680685.

Maejima, T., Ohya, Y., Mitsuhashi, S. \& Inoue, M. (1987). Cloning and expression of the gene(s) for chromosomal mediated $\beta$-lactamase production of Proteus vulgaris in Escherichia coli. Plasmid 18, 120 126.

Maniatis, T., Fritsch, E. F. \& Sambrook, J. (1982). Molecular Cloning. A Laboratory Manual. Cold Spring Harbor, NY: Cold Spring Harbor Laboratory.

Nicolas, M. H., Honore, N., Jarlier, V., Philippon, A. \& Cole, S. T. (1987). Molecular genetic analysis of cephalosporinase production and its role in $\beta$-lactam resistance in clinical isolates of Enterobacter cloacae. Antimicrobial Agents and Chemotherapy 31, 295299.

Nossal, N. G. \& Heppel, L. A. (1966). The release of enzymes of osmotic shock from Escherichia coli in exponential phase. Journal of Biological Chemistry 241, 3055-3062.

Ross, G. W. \& O'CallaGhan, C. H. (1975). $\beta$-Lactamase assays. Methods in Enzymology 43, 69-85.

SilhaVy, T. J., Berman, M. L. \& EnQuist, L. W. (1984). Experiments with Gene Fusions, p. 137. Cold Spring Harbor, NY: Cold Spring Harbor Laboratory.

SOUTHERN, E. M. (1975). Detection of specific sequences among DNA fragments separated by gel electrophoresis. Journal of Molecular Biology 98, 503-517. 